\title{
Technical Modernization of Station 3 Boiler Unit of Trypillia Thermal Power Station in Terms of Using Non-Standard Fuel
}

\author{
Oksana Yurasova $^{a}{ }^{\text {, }}$, Mykhailo Semerak $^{a}$, Stepan Lys $^{a}$, Mykhailo Klub ${ }^{b}$ \\ ${ }^{a}$ Lviv Polytechnic National University, 12 S. Bandera St., Lviv, 79013, Ukraine \\ b"Spetstermomontazh-Energo" LLC, 23 Y. Sverstiuk St., Kyiv, 02660, Ukraine
}

Received: March 03, 2020. Revised: May 23, 2020. Accepted: May 29, 2020.

(C) 2020 The Authors. Published by Lviv Polytechnic National University.

\begin{abstract}
The research focuses on making flow and thermal calculations for the pulverized coal systems, pulverized coal feeding and combustion of gas coal in the TPP-210A boiler in order to develop major engineering solutions for converting the station 3 boiler to gas coal. It also aims to assess the temperature conditions of safe operation of the boiler heating surfaces, following the formulation of major engineering solutions. Based on the analysis of the options and experience of the technical modernization of the station 4 boiler, the process flow diagram for gas coal pulverization was constructed with the maximum use of the available equipment and in compliance with the effective fire and explosion hazard regulations. There were performed flow and heat calculations of the pulverized coal system for the selected option in the operation and start/stop modes with determining the drying capacity of the pulverized coal system and the range of pulverized coal rate for different coal grades. The coal-air mixture speed in the pulverized coal ducts and burner channels was calculated and recommendations for the adaptation of the existing burners for gas coal were formulated. The choice of the pulverized coal system for the station 3 boiler with the maximum use of the available equipment and in keeping with RD 34.03.352-89 (Explosion Hazard Regulations for Fuel Feed, Pulverized-Coal and Combustion Systems) and other regulatory requirements was substantiated.
\end{abstract}

Keywords: anthracite; gas coal; pulverized combustion; pulverization; thermal calculation.

\section{Statement of the research problem}

Under the Ukraine's President Decree No. 37/2017 “On the Resolution of the National Security and Defence Council of Ukraine of February 16, 2017 "On Immediate Measures for the Elimination of Threats to Ukraine's Energy Security and Strengthening of Vital Infrastructure" and according to the schedule of repairs of major equipment of thermal power stations (Annex 2 to the Order No. 622 of the Ministry of Energy and Coal Mining of September 25, 2017 "On Preparation of Power Plants and Heating Networks to the Reliable and Efficient Operation in 2018 and Autumn/Winter 2019"), considering the positive experience of the technical modernization of the station 4 power generation unit of the Trypillia Thermal Power Station appertaining to its converting to gas coal, there arose the need for the development of design documentation and implementation of the measures aimed at converting the 300 MW pulverized coal power generation unit of the station 3 of the Trypillia Thermal Power Station to gas coal.

Therefore, the study aims at the analysis of the options, including the experience of the technical modernization of the station 4 power generation unit, pre-design calculations of the process flow diagrams for the systems of pulverization, pulverized coal feeding into the boiler and combustion in the TPP-210A boiler of the station 3 power generation unit of the Trypillia Thermal Power Station of gas flame coal and long flame coal (G and DG grades) with the maximum use of the available equipment packaging at different loads and for the starts and stops. It also provides

* Corresponding author. Email address: oksjanchyk@ gmail.com

This paper should be cited as: O. Yurasova, M. Semerak, S. Lys, M. Klub. Technical modernization of station 3 boiler unit of Trypillia thermal power station in terms of using non-standard fuel. Energy Engineering and Control Systems, 2020, Vol. 6, No. 1, pp. 23 - 32. https://doi.org/10.23939/jeecs2020.01.023 
for the assessment of the viable range of the power generation unit capacity when operating on G and DG grades of coal and substantiation of the set of engineering solutions for converting the station 3 boiler to gas coal.

\section{Analysis of the recent publications and studies}

In 2017, because of the termination of the Donetsk anthracite supply [1], [2] and according to the Ukraine's President Decree No. 37/2017, it was resolved to convert the station 4 boiler unit of the Trypillia Thermal Power Station to the combustion of gas coal. Within the framework of this project, the Institute of Renewable Energy of the National Academy the Sciences of Ukraine carried out the pre-design analysis of the options and design substantiation of the engineering solutions.

The major engineering solutions for the technical modernization of the station 4 boiler unit, as substantiated by the Institute of Renewable Energy of the National Academy the Sciences of Ukraine (as compared to the solutions applied to the boilers of the stations 2, 5 of the Zmiiv Thermal Power Station) consisted in the following [3], [4]:

- the number of coal pulverization systems was reduced from three to two (from one $100 \mathrm{MW}$ system to one 150 MW system, or per section);

- the use of two available hot-blast fans (HBF) as flue gas recirculation fans (FGRF) to ensure gas drying was substantiated;

- instead of four external cyclones, for the purification of the output flue gases it was proposed to install two compact ash collectors in the existing flue-gas duct;

- instead of inert gas flow at the temperature $130-170{ }^{\circ} \mathrm{C}$ from the inert gas fan (IGF) used for cooling at the start, scheduled or emergency stop of the coal pulverizer, the use of two spray gas coolers for cooling the gas flow from the FGRF was substantiated;

- instead of replacing the coal pulverizer fans (PF) with more powerful ones, it was substantiated that the existing PFs can be preserved due to the arrangement of transportation of high-concentration pulverized coal under a vacuum (HCPCv) with equipping the pulverized coal bunker with rotary-vane pulverized coal feeder in order to eliminate the air infiltration into the bunker via the pulverized coal leakages;

- instead of replacing the burners, it was substantiated that the existing burners can be used subject to their modernization and switching to the once-through vortex mode. The selected option provided for feeding the used drying agent to the primary air ducts of the main end burners instead of the dump burners. The other ducts (for the middle main burners, also the primary air duct) are fed with hot air. The pulverized coal is fed into the central duct of all the burners by the HCPCv steam ejectors. At that, the size dimensions of the burners do not change, except for the front ends of the central and primary air ducts, which are reduced 0.2-0.3-fold of the external dimeter of the burner (i.e. by 0.3-0.4 m).

The flow diagram of the burner with $\mathrm{HCPCv}$ after the reconstruction is shown in Fig.1. All the engineering solutions listed above were implemented during the technical modernization. As a result, the station 4 power generation unit was successfully launched and put into operation on gas coal; it has already functioned for over three months both in the double-section mode and each section functioning separately.

The boiler operation period showed that:

- the drying and pulverizing capacities of the pulverized coal systems on gas coal corresponded to the designed values; the $\mathrm{HCPCv}$ system operated steadily; there were no recorded cases of uncontrollable temperature increases and puffs in the pulverized coal system elements;

- the ash collectors demonstrated a sufficient effectiveness, no erosion of the HBF blades was observed;

- the flame length appeared to be shorter than the anthracite flame's and its value was such as to ensure steady ignition of the pulverized coal within a wide range of quality and loads of the boiler but too long to prevent scorching of the end elements of the burner; the pulsating feed of the pulverized coal did not interfere with the boiler operation; there were no recorded cases of pulverized coal separation to the bottom;

- the temperature modes of combustion corresponded to the design ones; the discharge of the liquid slag was unimpeded within the whole range of load regulation; there were no recorded authenticated cases of slagging of the platens caused by the drawing-up of the flame when combusting gas coal; there was no overheatingcaused damage of the screen walls; 
- within the period of operation and trial runs, the boiler unit reached the steam rate of 950-980 t/hr., and the electrical power of the unit was 270-280 MW (the reduction in the power with reference to the design value is caused by the above-mentioned decrease in the parameters of the main steam and reheat steam, aging and wearing out of the turbine and generator, insufficient performance of the fans at the available level of infiltration into the convection shaft and regenerative air heater (RAH);

- technical and economic indicators of combustion corresponded to those typical for pulverized coal boiler units on gas coal.

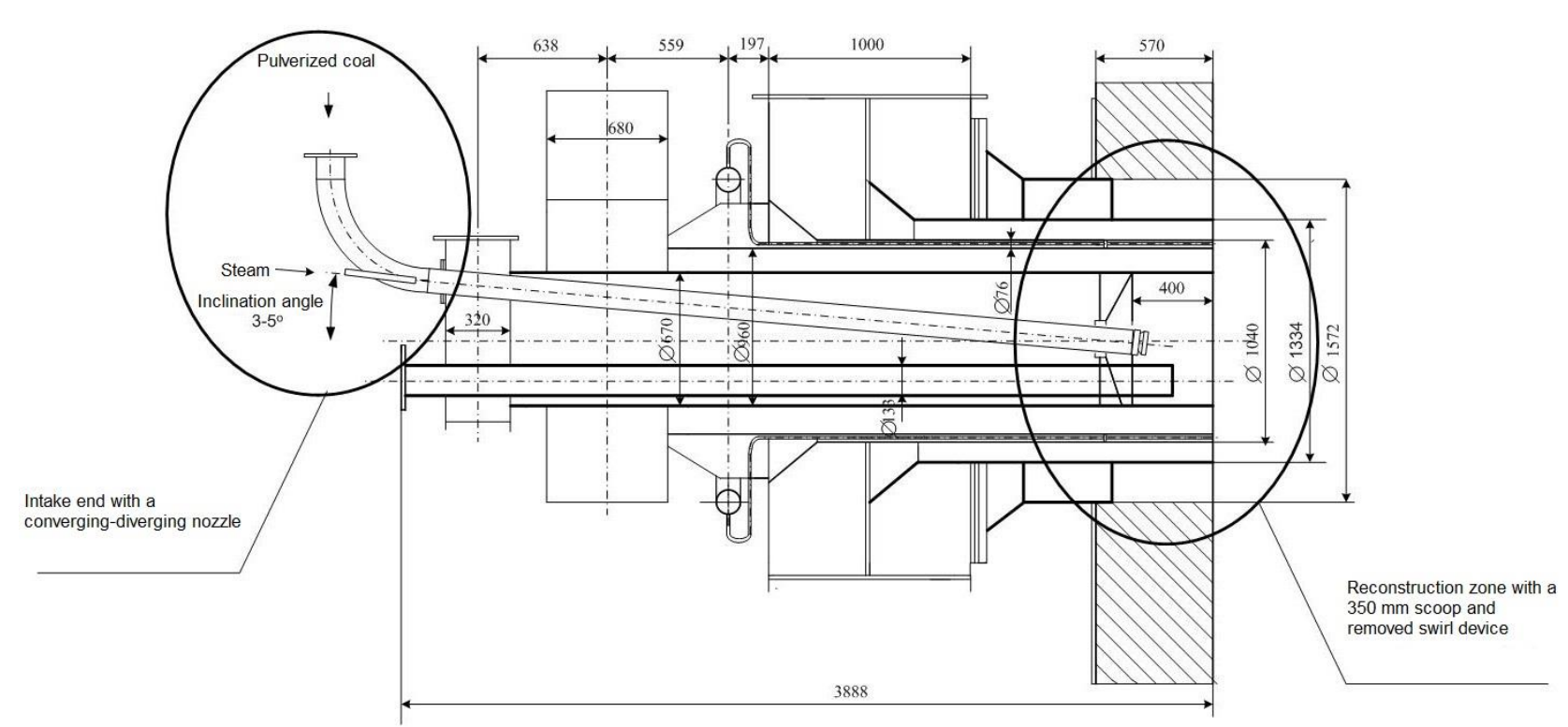

Fig.1. The flow diagram of adapting the existing burner of the station 4 TPP-210A boiler to gas coal.

At the same time, certain difficulties were revealed during the operation, which are being gradually eliminated at the starting-up and adjustment of the boiler but should be considered when developing engineering solutions for converting the station 3 boiler to gas coal.

1) The characteristics of the flue gases in the sampling cross-section on the section A appeared to correspond to the design values. On the section $\mathrm{B}$, because of the local infiltration of cold air into the convective shaft upwards of the sampling cross-section, in the cross-section itself the oxygen level and temperature gradients were found to be so high that the oxygen level in the flue gas samples exceeded $10 \%$, and their temperature was $100-120{ }^{\circ} \mathrm{C}$ below the design value. This problem was solved mainly owing to the installation of a deflector baffle above the sampling cross-section on the side of the mentioned infiltration. This said, for the station 3 boiler it is proposed that the flue gases should be sampled not from the wall zone but integrally from the flow in the design sampling crosssection (according to the water economizer). In the process of design, it is also necessary to consider adapting the infiltration path and HBF output to ensure the reduction of the draft loss with the optimization of the flue gas ducts, elimination of the local resistances, spare slide valves, etc.

2) The HBF production capacity appeared to be lower than the design value probably because of the additional pressure difference in the output duct. Due to that, the pressure at the pulverizer inlet for the closed air admixing sometimes exceeded $100 \mathrm{~mm} \mathrm{H}_{2} \mathrm{O}$. To avoid excessive pressure drop at the pulverizer inlet, on the pulverized coal systems of the station 4 boiler the admixing of hot and cold air are opened; this is envisaged in the design project but causes the risk of over $16 \%$ exceedance of the oxygen concentration in the drying agent. This considered, for the station 3 boiler, increasing the HBF production capacity within the available range of the electric drive power or replacing the existing $\mathrm{HBF}$ with a one with a higher production capacity are considered.

3) After the lengthy adjustment aimed at selecting the optimal water pressure at the inlet of the spray coolers depending on the temperature of the flue gases, the system proved feasible and efficient for maintaining a safe 
temperature of the drying agent in the modes of the pulverizer burnout. At the same time, due to the incomplete evaporation of the sprayed water and/or uneven temperature distribution in the flow, there is still observed a discharge of the collected condensate from the coolers. This considered and in order to provide an additional means of coal-air mixture temperature control when pulverizing dry run-of-mine coal, the station proposes additional equipping of the pulverized coal systems of the station 3 boiler with an inert gas fan (IGF), using spray coolers mostly for emergency spray in compliance with the RD 34.03.352-89 regulations.

4) The option of feeding the used drying agent to the primary air ducts of the main end burners instead of the dump burners with hot air feed into the other ducts (for the middle main burners, also into the primary air duct) and pulverized coal into the central duct of all the burners by the HCPCv steam ejectors proved to be feasible and efficient, in particular with respect to the gas speed in the burner duct for obtaining the flame with an optimal length and with respect to the pulverized coal combustion efficiency. At the same time, this option turned out to be quite complicated in terms of adjustment and routine regulation. Firstly, due to the presence of 10-15\% pulverized coal in the used drying agent, for equal productivities of all the pulverized coal feeders the middle burners get on average by $13 \%$ less pulverized coal than the end burners. This can be prevented either by separate regulation of the productivity of the pulverized coal feeders or by regulation the blade gaps. Second, for the adopted scheme of distributing the air flow between the main burners' louvers, the drying agent flow into the primary air duct of the end burners remains unchanged as the load changes, and the hot air flow into the primary air duct of the middle burners changes depending on the boiler load. This makes it necessary to regulate the air distribution between the louvers of different burners. This considered, for the station 3 boiler unit, the station proposed considering the possibility of the used drying agent discharge onto the existing dump burners.

5) For the schematic diagram of the pulverized coal system proposed and implemented in the station 4 boiler, it was recommended that coal with moisture of over $8 \%$ should be used, which enabled simplifying the schematic diagram by abandoning the drying agent recirculation from the PF outlet into the pulverizer inlet. Among the gas coal types proposed for supply to the Trypillia Thermal Power Station there is Lviv-Volyn run-of-mine coal with the moisture below 6\%, which makes it imperative to go back to the issue of the drying agent recirculation for the station 3 pulverized coal system.

6) The starting-up and adjustment process revealed that the pulverizing fineness cannot be regulated by regulating the position of the separator flaps (when the flaps are completely open, the pulverizing fineness becomes no coarser than 19\% residue on a $R_{90}$ mesh, whereas the norm prescribes $R_{90} \geq 20-24 \%$ ). For further regulation of the pulverizing fineness, it is planned that the internal piece of the separator should be shortened from $1 / 3$ to $2 / 3$ of its current length.

In addition, the thermal power station staff reports a significantly higher slag output for the operation of the station 4 boiler on gas coal. Taking into consideration that the ash content of gas coal rose only slightly, as compared to anthracite, this suggests that an increased portion of the ash is discharged with the slag $\mathbf{a}_{\mathrm{sl}}$ and is correlated with the GKD 34.09.103-96 data for a half-open combustion chamber $\left(\mathbf{a}_{\mathbf{s l}}=0.15\right.$ for anthracite and $\mathbf{a}_{\mathbf{s l}}=0.2-0.3$ for gas coal). This should be considered in a verification zoned thermal calculation of the combustion chamber and when forming a list of additional equipment.

For performing the corresponding calculations, it is necessary to select a sample fuel to be used for the operation of the modernized boiler unit. The experience of the technical modernization of the station 4 boiler unit showed that the criteria for selecting a sample fuel should include not only the calorific value, ash content and total moisture, but also the sulphur content determining the expected levels of sulphur dioxide, which must not exceed the permissible value. The expected fly ash emissions after the existing electric filters must also be below the permissible level.

For the selection of a sample fuel, the following coal types were proposed:

- DGR 0-200 mm run-of-mine coal, Novovolynsk Coal Mine 9, Volynvuhillia State-Run Company, (Certificate No. 22);

- G(G2) R 0-200 mm run-of-mine coal, Stepova Coal Mine, Volynvuhillia State-Run Company, (Certificate No. 186);

- DG 0-100 mm coal concentrate, Pavlohrad Coal-Preparation Plant, DTEK Pavlohradcoal PRJSC (Certificate No. 204).

The main characteristics of the proposed coal types are presented in Table 1. 
Table 1. The characteristics of the proposed coal types and sample coal mixture.

\begin{tabular}{|c|c|c|c|c|}
\hline Characteristic & $\begin{array}{c}\text { DGR } \\
\text { Cert. No. } 22\end{array}$ & $\begin{array}{c}\text { G(G2)R } \\
\text { Cert. No. } 186\end{array}$ & $\begin{array}{c}\text { DG 0-100 } \\
\text { Cert. No. } 204\end{array}$ & $\begin{array}{c}\text { Mixture } 40 \% \text { G(G2)R Cert. No. } 186+60 \% \text { DG } \\
\text { 0-100 Cert. No. } 204\end{array}$ \\
\hline $\mathrm{W}_{\mathrm{t}}^{\mathrm{r}}, \%$ & 4.8 & 6.5 & 15.1 & 11,66 \\
\hline $\mathrm{W}^{\mathrm{ri}}, \%$ & 4.25 & 1.93 & 4.77 & 3.6 \\
\hline $\mathrm{A}^{\mathrm{d}}, \%$ & 29.5 & 27.8 & 20.6 & 21.74 \\
\hline $\mathrm{V}^{\mathrm{daf}}, \%$ & 39.9 & 37.5 & 42.3 & 39.5 \\
\hline $\mathrm{S}_{\mathrm{t}}^{\mathrm{d}}, \%$ & 1.4 & 2.0 & 1.25 & 1.47 \\
\hline $\mathrm{Q}_{\mathrm{i}}^{\mathrm{r}}, \mathrm{kcal} / \mathrm{kg}$ & 4934 & 5212 & 5178 & 5195 \\
\hline $\mathrm{C}^{\mathrm{daf}}, \%$ & 82.18 & 82.15 & 86.27 & 56.27 \\
\hline $\mathrm{H}^{\mathrm{daf}}, \%$ & 5.72 & 5.95 & 4.32 & $3, .43$ \\
\hline $\mathrm{O}^{\mathrm{daf}}, \%$ & 10.18 & 8.41 & 7.22 & 5.22 \\
\hline $\mathrm{N}^{\mathrm{daf}}, \%$ & 1.60 & 1.60 & 1.60 & 1.07 \\
\hline $\mathrm{S}^{\mathrm{daf}}, \%$ & 0.32 & 1.89 & 0.59 & - \\
\hline $\mathrm{A}^{\mathrm{r}}, \%$ & 28.08 & 25.99 & 17.49 & 20.89 \\
\hline $\mathrm{C}^{\mathrm{r}}, \%$ & 54.23 & 54.96 & 57.58 & 56.53 \\
\hline $\mathrm{H}^{\mathrm{r}}, \%$ & 3.77 & 3.98 & 2.88 & 3.32 \\
\hline $\mathrm{O}^{\mathrm{r}, \%}$ & 6.72 & 5.63 & 4.82 & 5.14 \\
\hline $\mathrm{N}^{\mathrm{r}}, \%$ & 1.06 & 1.07 & 1.07 & 1.07 \\
\hline $\mathrm{S}^{\mathrm{r}}, \%$ & 1.33 & 1.87 & 1.06 & 1.38 \\
\hline $\mathrm{t}_{\mathrm{A}},{ }^{\circ} \mathrm{C}$ & $>1400$ & 1210 & 1270 & 1240 \\
\hline $\mathrm{t}_{\mathrm{C}},{ }^{\circ} \mathrm{C}$ & $>1400$ & 1290 & 1360 & 1330 \\
\hline HGI & 62 & 68 & 56 & 62 \\
\hline
\end{tabular}

The preliminary estimates showed that the Certificate No. 186 coal does not conform to the sulphur dioxide permissible level regulations. The sulphur dioxide level for the Certificate No. 204 coal is well below the permissible level, but its moisture exceeds the drying capacity of the pulverizers. Therefore, the Certificate No.22 was taken as the first sample fuel and the mixture 40\% Certificate No. 186 coal and 60\% Certificate No. 204 coal was used as the second sample fuel. The characteristics of this mixture are also presented in Table 1.

\section{Aim of the research}

The study focuses on the analysis of the technical modernization options, including the experience of the station 4 power generation unit, pre-design calculations of the process flow diagrams for the pulverized coal systems, pulverized coal feeding into the boiler and combustion of G and DG coal grades in the TPP-210A boiler of the station 3 power generation unit of the Trypillia Thermal Power Station with maximum preservation of the available equipment packaging at different loads, at the starts and stops. It also provides for the assessment of the viable range of the power generation unit capacity when operating on G and DG coal grades and substantiation of the set of engineering solutions for converting the station 3 boiler to gas coal.

\section{Results and their discussion}

\subsection{Engineering solutions and results of the flow and thermal calculations of the pulverized coal system in the operation modes at different loads}

The flow and thermal calculation of the pulverized coal system was performed using the standard method with some simplifications due to its verifying nature:

- the optimal loading of the balls and optimal flow of the drying agent through the pulverizer were not calculated and were taken as known data;

- the recirculation of the drying agent from the PF outlet into the pulverizer inlet was not used in the first approximation;

- for the set values of the PF flow and levels of cold air (CA) infiltration, the proportion of the flows of the flue gases (FG), hot air (HA) and CA varied until the moment when the imbalance became below $\pm 0.2 \%$ for the oxygen concentration of no more than $16 \%$.

The selection of the design pulverized coal moisture relied on the fact that to ensure a sufficient flowability, on the one hand, and to avoid over-drying of the pulverized coal for preventing increase in its explosiveness, on the 
other, the optimal range of the pulverized coal moisture is $\mathrm{W}^{\mathrm{pc}}=(0.5-1.0) \mathrm{W}^{\text {hy }}$, where $\mathrm{W}^{\text {hy }}$ is the hygroscopic moisture (see Table 2).

The calculation considered that in the first approximation the output of the exhaust fans in real $\mathrm{m}^{3}$ is temperature-independent. In contrast to the calculations for the boiler of the station 4 power generation unit, the calculation included the inert gas flow from IGF, which was obligatory in the burnout modes and in the operation modes when required.

Table 2. The main results of the flow and thermal calculations of the pulverized coal systems of the station 3 boiler for the sample coal (DGR) for the reduced infiltration levels

\begin{tabular}{|c|c|c|c|c|}
\hline Load, \% & $100 \%$ & $90 \%$ & $80 \%$ & $70 \%$ \\
\hline \multicolumn{5}{|l|}{ Source data: } \\
\hline Pulverized coal rate, $\mathrm{t} / \mathrm{hr}$. & 68,2 & 61,4 & 54,6 & 47,8 \\
\hline Calorific value, $\mathrm{kcal} / \mathrm{kg}$ & 4934 & 4934 & 4934 & 4934 \\
\hline Stoichiometric air flow, $\mathrm{nm}^{3} / \mathrm{t}$ & 5746 & 5746 & 5746 & 5746 \\
\hline Number of pulverized coal systems & 2 & 2 & 2 & 2 \\
\hline Coal equivalent rate per boiler, $\mathrm{t} / \mathrm{hr}$. & 96.1 & 86.6 & 77.0 & 67.3 \\
\hline Boiler heat output, Gcal $/ \mathrm{hr}$ & 610 & 549 & 488 & 427 \\
\hline Boiler heat output, $\%$ of the rated value & 1.000 & 0.900 & 0.800 & 0.700 \\
\hline Coal moisture, \% & 4.8 & 4.8 & 4.8 & 4.8 \\
\hline Pulverized coal moisture, \% & 2.0 & 2.0 & 2.0 & 2.0 \\
\hline Evaporated moisture, t/hr. & 1.95 & 1.75 & 1.56 & 136 \\
\hline PF flow, thou. $\mathrm{m}^{3} / \mathrm{hr}$. & 125.0 & 125.0 & 125.0 & 125.0 \\
\hline PF flow, thou. $\mathrm{nm}^{3} / \mathrm{hr}$. & 90.3 & 89.8 & 88.2 & 87.3 \\
\hline FG flow, thou. $\mathrm{m}^{3} / \mathrm{hr}$. & 83.1 & 80.9 & 82.6 & 82.9 \\
\hline FG flow, thou. $\mathrm{nm}^{3} / \mathrm{hr}$. & 36.4 & 35.5 & 36.2 & 36.9 \\
\hline HA flow, thou. $\mathrm{m}^{3} / \mathrm{hr}$. & 0.0 & 0.0 & 0.0 & 0.0 \\
\hline HA flow, thou. $\mathrm{nm}^{3} / \mathrm{hr}$. & 0.0 & 0.0 & 0.0 & 0.0 \\
\hline CA (admixture) flow, thou. $\mathrm{m}^{3} / \mathrm{hr}$. & 23.8 & 24.6 & 22.2 & 20.7 \\
\hline CA (admixture) flow, thou. $\mathrm{nm}^{3} / \mathrm{hr}$. & 21.5 & 22.2 & 20.0 & 18.7 \\
\hline CA infiltration, thou. $\mathrm{m}^{3} / \mathrm{hr}$. & 33.3 & 33.3 & 33.3 & 33.3 \\
\hline CA infiltration, thou. $\mathrm{nm}^{3} / \mathrm{hr}$. & 30.0 & 30.0 & 30.0 & 30.0 \\
\hline CA infiltration, \% & 51.9 & 52.1 & 53.3 & 54.0 \\
\hline IG flow, thou. $\mathrm{m}^{3} / \mathrm{hr}$. & 0.0 & 0.0 & 0.0 & 0.0 \\
\hline IG flow, thou. $\mathrm{m}^{3} / \mathrm{hr}$. & 0.0 & $0, .0$ & 0.0 & 0.0 \\
\hline FG temperature, ${ }^{\circ} \mathrm{C}$ & 350 & 350 & 350 & 340 \\
\hline HA temperature, ${ }^{\circ} \mathrm{C}$ & 320 & 320 & 320 & 320 \\
\hline CA temperature, ${ }^{\circ} \mathrm{C}$ & 30 & 30 & 30 & 30 \\
\hline IG temperature, ${ }^{\circ} \mathrm{C}$ & 130 & 130 & 130 & 130 \\
\hline $\mathrm{O}_{2}$ concentration in $\mathrm{FG}, \%$ & 6.62 & 6.97 & 7.42 & 7.84 \\
\hline $\mathrm{H}_{2} \mathrm{O}$ concentration in $\mathrm{FG}, \%$ & 7.35 & 7.20 & 7.08 & 6.94 \\
\hline $\mathrm{O}_{2}$ concentration in IG, $\%$ & 8.87 & 9.06 & 9.26 & 9.46 \\
\hline $\mathrm{H}_{2} \mathrm{O}$ concentration in $\mathrm{IG}, \%$ & 6.60 & 6.53 & 6.47 & 6.40 \\
\hline Temperature after the pulverizer, ${ }^{\circ} \mathrm{C}$ & 105 & 107 & 114 & 118 \\
\hline \multicolumn{5}{|l|}{ Generated heat, Mcal/hr.: } \\
\hline Drying agent heat & 4259.9 & 4148.7 & 4236.4 & 4195.0 \\
\hline Heat from the milling bodies & 1231.4 & 1108.6 & 985.9 & 862.2 \\
\hline CA heat & 486.6 & 493.4 & 473.2 & 460.4 \\
\hline \multicolumn{5}{|l|}{ Heat flow rate, Mcal/hr.: } \\
\hline Evaporation heat & 1255.6 & 1132.0 & 1011.8 & 887.4 \\
\hline Heat of the used drying agent & 2957.6 & 3005.2 & 3152.4 & 3238.9 \\
\hline Heat capacity of the dried pulverized coal, $\mathrm{Kcal} /(\mathrm{kg} \cdot \mathrm{K})$ & 0.26 & 0.26 & 0.26 & 0.26 \\
\hline Heat for pulverized coal heating & 1464.2 & 1349.2 & 1296.3 & 1181.9 \\
\hline Wall heat loss & 293.2 & 264.0 & 234.7 & 205.3 \\
\hline Imbalance, $\%$ & 0.1 & $\mathbf{0 . 0}$ & $\mathbf{0 . 0}$ & 0.1 \\
\hline \multicolumn{5}{|l|}{ In the used drying agent: } \\
\hline $\mathrm{H}_{2} \mathrm{O}, \%$ by vol. & 7.1 & 6.7 & 6.6 & 6.3 \\
\hline Dew point, ${ }^{\circ} \mathrm{C}$ & 40.6 & 39.8 & 39.2 & 38.6 \\
\hline $\mathrm{O}_{2}, \%$ by vol. & 14.4 & 14.7 & 14.7 & 14.7 \\
\hline $\mathrm{O}_{2}, \%$ by vol. dry & 15.4 & 15.7 & 15.7 & 15.7 \\
\hline Speed at PF output, $\mathrm{m} / \mathrm{s}$ & 25.4 & 25.4 & 25.4 & 25.4 \\
\hline Speed after the flow splitter, $\mathrm{m} / \mathrm{s}$ & 37.9 & 37.9 & 37.9 & 37.9 \\
\hline
\end{tabular}


Table 3. The main results of the flow and thermal calculations of the pulverized coal systems of the station 3 boiler for ASh and sample fuels for the existing infiltration levels

\begin{tabular}{|c|c|c|c|c|c|}
\hline \multirow{2}{*}{$\begin{array}{ll}\text { Coal } & \text { Coad, \% } \\
\text { Loa }\end{array}$} & \multirow{2}{*}{$\begin{array}{l}\text { ASh } \\
\text { max. }\end{array}$} & \multicolumn{2}{|c|}{$\begin{array}{c}\text { DGR } \\
\text { Cert. No. } 22\end{array}$} & \multicolumn{2}{|c|}{$\begin{array}{c}\text { Mixture } \\
40 \% \text { Cert. No. } 186+ \\
60 \% \text { Cert. } \text { No. } 204 \\
\end{array}$} \\
\hline & & $\max$. & $\min$. & $\max$ & $\min$. \\
\hline \multicolumn{6}{|l|}{ Source data: } \\
\hline Pulverized coal rate, $\mathrm{t} / \mathrm{hr}$. & 40.8 & 68.2 & 47.8 & 64.9 & 45.4 \\
\hline Calorific value, $\mathrm{kcal} / \mathrm{kg}$ & 5500 & 4934 & 4934 & 5192 & 5192 \\
\hline Stoichiometric air flow, $\mathrm{nm}^{3} / \mathrm{t}$ & 6510 & 5746 & 5746 & 5887 & 5887 \\
\hline Number of pulverized coal systems & 3 & 2 & 2 & 2 & 2 \\
\hline Coal equivalent rate per boiler, $\mathrm{t} / \mathrm{hr}$. & 96.2 & 96.1 & 67.3 & 96.2 & 67.3 \\
\hline Boiler heat output, Gcal/hr. & 610 & 610 & 427 & 610 & 427 \\
\hline Boiler heat output, $\%$ of the rated value & 1.000 & 1.000 & 0.700 & 1.000 & 0.700 \\
\hline Coal moisture, $\%$ & 8 & 4.8 & 4.8 & 11.7 & 11.7 \\
\hline Pulverized coal moisture, $\%$ & 0.7 & 2.0 & 2.0 & 3.0 & 3.0 \\
\hline Evaporated moisture, t/hr. & 3.02 & 1.95 & 1.36 & 5.82 & 4.07 \\
\hline PF flow, thou. $\mathrm{m}^{3} / \mathrm{hr}$ & 120.0 & 125.0 & 125.0 & 125.0 & 125.0 \\
\hline PF flow, thou. $\mathrm{nm}^{3} / \mathrm{hr}$. & 85.5 & 90.3 & 88.0 & 95.1 & 92.7 \\
\hline FG flow, thou. $\mathrm{m}^{3} / \mathrm{hr}$ & 0.0 & 83.1 & 77.0 & 97.2 & 99.9 \\
\hline FG flow, thou. $\mathrm{nm}^{3} / \mathrm{hr}$. & 0.0 & 36.4 & 34.3 & 42.6 & 44.5 \\
\hline HA flow, thou. $\mathrm{m}^{3} / \mathrm{hr}$. & 99.5 & 0.0 & 0.0 & 19.5 & 0.0 \\
\hline HA flow, thou. $\mathrm{nm}^{3} / \mathrm{hr}$. & 45.8 & 0.0 & 0.0 & 9.0 & 0.0 \\
\hline CA (admixture) flow, thou. $\mathrm{m}^{3} / \mathrm{hr}$. & 0.0 & 17.2 & 12.2 & 0.2 & 8.0 \\
\hline CA (admixture) flow, thou. $\mathrm{nm}^{3} / \mathrm{hr}$. & 0.0 & 15.5 & 11.0 & 0.2 & 7.2 \\
\hline CA infiltration, thou. $\mathrm{m}^{3} / \mathrm{hr}$. & 40.0 & 40.0 & 40.0 & 40.0 & 40.0 \\
\hline CA infiltration, thou. $\mathrm{nm}^{3} / \mathrm{hr}$. & 36.0 & 36.0 & 36.0 & 36.0 & 36.0 \\
\hline CA infiltration, $\%$ & 78.6 & 69.4 & 71.6 & 69.5 & 69.7 \\
\hline IG flow, thou. $\mathrm{m}^{3} / \mathrm{hr}$. & 0.0 & 0.0 & 7.4 & 0.0 & 0.0 \\
\hline IG flow, thou. $\mathrm{m}^{3} / \mathrm{hr}$. & 0.0 & 0.0 & 5.0 & 0.0 & 0.0 \\
\hline FG temperature, ${ }^{\circ} \mathrm{C}$ & - & 350 & 340 & 350 & 340 \\
\hline HA temperature, ${ }^{\circ} \mathrm{C}$ & 320 & 320 & 320 & 320 & 320 \\
\hline CA temperature, ${ }^{\circ} \mathrm{C}$ & 30 & 30 & 30 & 30 & 30 \\
\hline IG temperature, ${ }^{\circ} \mathrm{C}$ & 130 & 130 & 130 & 130 & 130 \\
\hline $\mathrm{O}_{2}$ concentration in $\mathrm{FG}, \%$ & 21.00 & 6.62 & 7.84 & 6.65 & 7.87 \\
\hline $\mathrm{H}_{2} \mathrm{O}$ concentration in $\mathrm{FG}, \%$ & 0.50 & 7.35 & 6.94 & 6.81 & 6.45 \\
\hline $\mathrm{O}_{2}$ concentration in $\mathrm{IG}, \%$ & 21.00 & 8.87 & 9.46 & 8.90 & 9.49 \\
\hline $\mathrm{H}_{2} \mathrm{O}$ concentration in $\mathrm{IG}, \%$ & 0.50 & 6.60 & 6.40 & 6.15 & 5.97 \\
\hline Temperature after the pulverizer, ${ }^{\circ} \mathrm{C}$ & 110 & 105 & 115 & 86 & 95 \\
\hline \multicolumn{6}{|l|}{ Generated heat, Mcal/hr.: } \\
\hline Drying agent heat & 4690.5 & 4259.9 & 4110.5 & 5907.1 & 5059.0 \\
\hline Heat from the milling bodies & 736.7 & 1231.4 & 862.2 & 1170.9 & 819.7 \\
\hline CA heat & 340.3 & 486.6 & 444.1 & 342.5 & 408.2 \\
\hline \multicolumn{6}{|l|}{ Heat flow rate, Mcal/hr.: } \\
\hline Evaporation heat & 1952.0 & 1255.6 & 885.5 & 3695.9 & 2604.6 \\
\hline Heat of the used drying agent & 2857.5 & 2957.6 & 3183.2 & 2425.2 & 2675.7 \\
\hline Heat capacity of the dried pulverized coal, $\mathrm{Kcal} /(\mathrm{kg} \cdot \mathrm{K})$ & 0.23 & 0.26 & 0.26 & 0.26 & 0.26 \\
\hline Heat for pulverized coal heating & 782.1 & 1464.2 & 1145.7 & 1013.0 & 805.9 \\
\hline Wall heat loss & 175.4 & 293.2 & 205.3 & 278.8 & 195.2 \\
\hline Imbalance, \% & $\mathbf{0 . 0}$ & 0.1 & -0.1 & 0.1 & 0.1 \\
\hline \multicolumn{6}{|l|}{ In the used drying agent: } \\
\hline $\mathrm{H}_{2} \mathrm{O}, \%$ vol. & 6.8 & 7.1 & 6.4 & 11.1 & 9.4 \\
\hline Dew point, ${ }^{\circ} \mathrm{C}$ & 39.9 & 40.6 & 38.7 & 49.1 & 45.8 \\
\hline $\mathrm{O}_{2}, \%$ by vol. & 19.6 & 14.4 & 14.5 & 12.7 & 13.3 \\
\hline $\mathrm{O}_{2}, \%$ by vol. dry & 21.0 & 15.4 & 15.5 & 14.3 & 14.7 \\
\hline Speed at PF output, $\mathrm{m} / \mathrm{s}$ & 24.4 & 25.4 & 25.4 & 25.4 & 25.4 \\
\hline Speed after the flow splitter, $\mathrm{m} / \mathrm{s}$ & 36.4 & 37.9 & 37.9 & 37.9 & 37.9 \\
\hline
\end{tabular}


From the beginning, it was assumed that the cold air infiltration into the pulverized coal systems after the reconstruction remained at the same level as it had been before the reconstruction and was in its turn determined by the calculation of the flow and thermal balance for ASh anthracite (Table 3). However, the operation indicators of the pulverized coal system of the station 4 boiler after the reconstruction revealed that the actual levels of infiltration into the pulverized coal systems are significantly lower. This was considered in the major calculations for the sample fuels at the boiler loads equal to 100, 90, 80 and $70 \%$ of the rated load (Table 2).

\subsection{The analysis of the calculation results}

The analysis of the calculation results suggests the following:

1) The rated load of the power generation unit operating on gas coal is achieved with as many as two pulverized coal systems.

2) The dew point in the used drying agent does not exceed $50{ }^{\circ} \mathrm{C}$, which prevents the risk of moisture condensation in the elements of the pulverized coal system and at the inlets to the burners.

3) To ensure the required flow of the hot flue gases to the drier, the real output of HBF used as FGRF, taking into consideration the need to overcome the additional pressure difference, should be no less than 100 thou. $\mathrm{m}^{3} / \mathrm{hr}$.

4) In the design calculation modes the temperature after the pulverizer does not exceed $120{ }^{\circ} \mathrm{C}$, the oxygen concentration in the drying agent does not exceed $16 \%$, the coal-air mixture speed in all sections of the pulverized coal ducts is below $25 \mathrm{~m} / \mathrm{s}$, which fully complies with the PTE and RD 34.03.352-89 regulatory requirements [5], [6].

5) The mode conditions for pulverizing the DGR coal containing $4.8 \%$ moisture and the mixture with $11.7 \%$ moisture differ significantly. When pulverizing the moister coal mixture at the rated load, for maintaining the thermal balance of the drier, hot air admixing is needed; when the load is reduced, maintaining the temperature after the ballmill pulverizer is ensured by reducing the admixing of hot air and adding cold air into the drying agent. For pulverizing the DGR run-of-mine coal, hot air is not used: to control the temperature rise even at rated load, coal air admixing is required. At the load equal to $70 \%$ of the rated one, in order to control the oxygen concentration in the drying agent the temperature of the coal-air mixture should be increased to the critical value of $118^{\circ} \mathrm{C}$.

The latter fact makes it necessary to consider applying the recirculation of the used drying agent from the PF outlet into the pulverizer inlet. In was said in [2] that the need for the recirculation of the used drying agent into the pulverizer inlet arises when the pulverizer designed for a high drying capacity is fed with relatively dry fuel. In such a case, either the temperature after the pulverizer must be increased or admixing of cold air must be increased with the risk of going beyond the regulatory limits for the temperature and/or oxygen concentration after the pulverizer. The drying agent recirculation helps reduce the temperature without adding cold air. However, at the technical modernization of the station 4 boiler the recirculation was dismissed. On the one hand, the coal with the moisture of over $8 \%$ was considered as a sample fuel. On the other, due to the presence of a horizontal section between the PF and the flow splitter, the offtake of part of the coal-air mixture flow would cause the reduction of the speed down to less than $25 \mathrm{~m} / \mathrm{s}$, which is unacceptable according to the regulatory requirements [6], [7].

The situation is different with the station 3 boiler. Firstly, the moisture of one of the sample fuels (DGR Cert. No. 22 ) is $4.8 \%$, which makes it impossible to maintain the temperature of the coal-air mixture at the acceptable level by means of admixing cold air only. Secondly, the engineering staff of the thermal power station found a solution for inserting a junction for the offtake for recirculation after the horizontal section, in the ascending section of the pulverized coal duct.

\subsection{Recommendations for adapting the existing burners to gas coal combustion}

Based on the calculation results, instead of replacing the burners it is proposed to keep the existing burners subject to their modernization and switching to once-through vortex mode [8]. As in case of the burners of the station 4 boiler, the pulverized coal is fed into the central duct of all the burners by the HCPCv steam ejectors. At that, the size dimensions of the burners do not change, except for the front ends of the central and primary air ducts, which are reduced 0.2-0.3-fold of the external dimeter of the burner (i.e. by 0.3-0.4 m).

The difference with the station 4 boiler burners is that the used drying agent is discharged onto the dump burners. Whereas on the station 4 boiler burners the speed increase in the tubes of the burner, which is required according to the standard OST 108.030 .26 , was achieved by directing the drying agent to the main burners, in the 
proposed variant the same effect is achieved by opening or switching of the external primary air duct into the protective blow mode.

\section{Conclusion}

The paper presents the results of the pre-design calculations and analysis of the options for the process flow diagrams for the pulverized coal systems, pulverized coal feeding into the boiler and combustion of gas flame coal and long flame coal (G and DG grades) in the TPP-210A boiler of the station 3 power generation unit of the Trypillia Thermal Power Station with the maximum preservation of the available equipment packaging at different loads and for the starts and stops. It also provides the results of assessing the viable range of the power generating unit capacity when operating on $\mathrm{G}$ and $\mathrm{DG}$ grades of coal.

It was established that the rated load of the power generation unit when operated on the sample gas coal is achieved by operating only two pulverized coal systems. The dew point in the used drying agent does not exceed $50{ }^{\circ} \mathrm{C}$, which eliminates the risk of moisture condensation in all the pulverized coal system elements and at the inlets of the burners. To ensure the necessary flow of hot flue gases for the drying, the real output of the HBF used as FGRF (taking into account the need to overcome the additional pressure difference) should be no less than 100 thou. $\mathrm{m}^{3} / \mathrm{hr}$. In all the calculation modes, the temperature after the pulverizer does not exceed $120^{\circ} \mathrm{C}$, the oxygen concentration in the used drying agent does not exceed $16 \%$, and the coal-air mixture speed at all sections of the pulverized coal ducts is no less than $25 \mathrm{~m} / \mathrm{s}$, which fully complies with the PTE and RD 34.03.352-89 regulatory requirements. The mode conditions for pulverizing the DGR coal containing $4.8 \%$ moisture and the mixture with $11.7 \%$ moisture differ significantly. When pulverizing the moister coal mixture at the rated load, for maintaining the thermal balance of the drier, hot air admixing is needed; when the load is reduced, maintaining the temperature after the ball-mill pulverizer is ensured by reducing the admixing of hot air and adding cold air into the drying agent. For pulverizing the DGR run-of-mine coal, hot air is not used: to control the temperature rise even at rated load, coal air admixing is required. At the load equal to $70 \%$ of the rated one, in order to control the oxygen concentration in the drying agent the temperature of the coal-air mixture should be increased to the critical value of $118{ }^{\circ} \mathrm{C}$.

According to the calculation results, instead of replacing the burners, it is proposed to keep the existing burners subject to their modernization and switching to the once-through vortex mode. Similarly to the station 4 boiler burners, the pulverized coal is fed into the central duct of all the burners by the HCPCv steam ejectors. At that, the size dimensions of the burners do not change, except for the front ends of the central and primary air ducts, which are reduced 0.2-0.3-fold of the external dimeter of the burner (i.e. by 0.3-0.4 m).

\section{References}

[1] S. Lys, O. Yurasova, N. Lashkovska. Methods of extending the life cycle of a TP-100A boiler. Energy Engineering and Control Systems, 2018, Vol. 4, No. 1, pp. 1 - 8. https://doi.org/10.23939/jeecs2018.01.00

[2] M.V. Cherniavskyi, O.V. Moiseienko, T.M. Monastyriova. History and prospects of using coal at Ukraine's thermal power stations from the point of view of reducing greenhouse gas emission. Proceedings of the $13^{\text {th }}$ International Scientific and Practical Conference "Coal Thermal Power Engineering: Ways of Reconstruction and Development”. Kyiv, Institute of Renewable Energy of National Academy of Sciences of Ukraine, 2017, pp. 21-27. (in Ukrainian)

[3] Analysis of the Options and Design Substantiation of the Engineering Solutions for Further Development and Implementation of the Project for Technical Modernization of the Station 4 Boiler Unit of the Trypillia Thermal Power Station with Regard to Using Non-Design Fuel (G, DG coal grades) at 1 Promyslova Street, Ukrainka, Obukhiv District, Kyiv Region: Report on the Scientific Research Project under the Agreement No. 5/17 of 31/05/2017 (closing) / Project Manager: Cherniavskyi, M.V. Kyiv, Institute of Renewable Energy, National Academy Sciences of Ukraine, 2017. (in Ukrainian)

[4] M.V. Cherniavskyi, Ye.S. Miroshnychenko, O.Yu. Provalov. Analysis of the Options and Design Substantiation of the Engineering Solutions for Converting the TPP-210A Boiler of the Trypillia Thermal Power Station to Gas Coal. Proceedings of the $13^{\text {th }}$ International Scientific and Practical Conference "Coal Thermal Power Engineering: Ways of Reconstruction and Development". Kyiv, Institute of Renewable Energy of National Academy of Sciences of Ukraine, 2017, pp. 86-90. (in Ukrainian)

[5] GKD 34.20.507-2003 Technical Operation of Power Stations and Networks: Regulations. (in Ukrainian)

[6] RD 34.03.352-89 Explosion Hazard Regulations for Fuel Feed, Pulverized-Coal and Combustion Systems. (in Russian)

[7] RD 34.24.501-96 Operation Manual for Pulverized Coal Systems with Ball-Mill Pulverizers and a Pulverized Coal Storage System. (in Russian)

[8] Golyshev, L.V., Vinnitskii, I.P., Fil', S.A. et al. Economic Parameters of the Coal-Fired TPP-210A Boiler under Nonstationary Operating Modes. Power Technology and Engineering 37, 302-305 (2003). https://doi.org/10.1023/B:HYCO.0000009797.86215.08 


\title{
Технічне переоснащення котлоагрегату станції №3 Трипільської ТЕС в частині використання непроектного палива
}

\author{
Оксана Юрасова ${ }^{a}$, Михайло Семерак ${ }^{a}$, Степан Лис ${ }^{a}$, Михайло Клуб ${ }^{b}$ \\ ${ }^{a}$ Наиіональний університет «Львівська політехніка», вул. С. Бандери 12, Львів, 79013, Україна \\ ${ }^{b} \mathrm{~T} О В$ «Спецтермомонтаж-Енерго», вул. С. Сверстюка, 23, Київ, О2660, Украйна
}

\begin{abstract}
Анотація
Завданням роботи $\epsilon$ виконання витратно-теплових розрахунків по системах приготування пилу, подачі пилу в котел та спалюванню в котлі ТПП-210А вугілля газової групи для визначення основних технічних рішень 3 переведення котла станції №3 на спалювання вугілля газової групи; виконання розрахунків забезпечення температурних умов безпечної експлуатації поверхонь нагріву котла після визначення основних технічних рішень. На підставі аналізу варіантів та досвіду технічного переоснащення котла станції №4 визначено технологічну схему для приготування пилу з вугілля газової групи 3 максимальним використанням наявного обладнання і згідно з чинними нормативними вимогами пожежо- та вибухобезпеки. Виконано витратно-теплові розрахунки пилосистеми за визначеним варіантом в режимах експлуатації та пусків-зупинів 3 визначенням сушильної продуктивності пилосистеми та діапазону витрати пилу для різної якості вугілля. Виконано розрахунки швидкості аеросуміші в пилопроводах та каналах пальників, надано рекомендації 3 адаптації існуючих пальників під газове вугілля. Обгрунтовано вибір схеми пилоприготування для котла станції №3 з максимальним використанням наявного обладнання, дотриманням РД 34.03.352-89 та інших нормативних вимог з безпечної експлуатації.
\end{abstract}

Ключові слова: антрацит; газове вугілля; пиловидне спалювання; пило приготування; тепловий розрахунок. 